\title{
Chromosome number in Brazilian germplasm accessions of Paspalum hydrophilum, P. modestum and P. palustre (Gramineae; Paniceae)
}

\author{
Marisa T. Pozzobon and José F.M. Valls \\ Embrapa Recursos Genéticos e Biotecnologia (CENARGEN), Parque Estação Biológica - PqEB, \\ Brasília, DF, Brazil.
}

\begin{abstract}
This paper compiles results of chromosome counts of Paspalum hydrophilum, $P$. modestum and P. palustre. Four Brazilian accessions of $P$. modestum have shown $2 \mathrm{n}=2 \mathrm{x}=20$ chromosomes, a number already found in one accession from Argentina and in two from Brazil. Three other Brazilian accessions showed tetraploid level $(2 n=4 x=$ 40), which was previously unknown in this species. In $P$. hydrophilum, only one of the accessions analyzed presented tetraploid level, initially established for the species from plants collected in Argentina. Five additional accessions from Brazil showed the diploid number, previously detected in a single Brazilian population. A tetraploid cytotype was found in $P$. palustre, previously known as a diploid species. In addition to confirming the occurrence of distinct ploidy levels for all three species, the results establish the predominance of the diploid level in $P$. hydrophilum and $P$. modestum accessions collected in Brazil.
\end{abstract}

Key words: Grass, ploidy level, Paspalum hydrophilum, P. modestum, P. palustre.

Received: August 1, 2000; Accepted: May 12, 2003.

\section{Introduction}

Similar in their hydrophilic behaviour, Paspalum hydrophilum Henrard, P. modestum Mez and P. palustre Mez have attracted the attention of agrostologists as promising forage grasses, capable of producing significant amounts of high-quality forage in areas subject to floods. Barreto (1954) considered P. palustre as an additional member of the informal group Virgata, established by Chase (1929), as the species shows a brownish upper floret. Later on, he included P. modestum and P. hydrophilum, both sharing the brownish upper floret, in his new informal group Modesta (Barreto, 1974), which also encompasses $P$. boscianum Fluegge, characterized by Quarín and Hanna (1980) as a sexual, self-compatible tetraploid. Obviously related to $P$. modestum, as concluded on morphological and ecological grounds, but not occurring in the geographical area covered by the 1974 study, $P$. palustre was not formally included by Barreto in his group Modesta. $P$. modestum had previously been mentioned by Chase (1929) as a South-American species related to $P$. montembense Léon, P. wrightii Hitchc. \& Chase, and P. leptachne Chase,

Send correspondence to MarisaT.Pozzobon. Embrapa Recursos Genéticos e Biotecnologia (CENARGEN), Parque Estação Biológica - PqEB, Final Av. W3 Norte, Caixa Postal 02372, 70770-900 Brasília, DF, Brazil. E-mail: marisa@cenargen.embrapa.br. all included, along with $P$. boscianum, in the informal group Plicatula.

The geographic distribution of $P$. modestum, $P$. hydrophilum and $P$. palustre in Brazil is quite distinct: Paspalum modestum is restricted to the southern half of Rio Grande do Sul, the southernmost Brazilian State, and is frequent in lowlands and river edges of three physiographic regions, the Depressão Central, Litoral, and Campanha (Barreto, 1974). It also occurs in adjacent areas of Argentina and Uruguay (Burkart, 1969). Araújo (1934) stressed the potential of this species for productive agricultural use of swamp areas. As it was first located in the Santa Carmen swamp, in the municipality of Uruguaiana, the species is locally called "Grama de Santa Carmen" (Santa Carmen grass) (Araújo, 1934; 1971).

Paspalum hydrophilum is frequent in areas of the periodically flooded "Mato Grosso Pantanal" region, in the Paraguay river drainage, in the Central Brazilian states of Mato Grosso and Mato Grosso do Sul, and along the Xingu and Araguaia rivers, which drain to the Amazon basin, respectively in the states of Mato Grosso and Tocantins. It can be the dominant species over extensive natural grasslands, offering a substantial amount of tender forage. According to Allem and Valls (1987), among other promising native grasses, investigation of the forage potential and adequate management of this species in the "Pantanal" de- 
serves high priority. In Rio Grande do Sul, P. hydrophilum is a rare species, occasionally found in swamps of the southern Litoral region (Barreto, 1974). The natural area of $P$. hydrophilum in the "Pantanal" proceeds down the Paraguay river basin into Paraguay (Henrard, 1922) and the Argentinian Province of Chaco (Norrmann, 1981). The mention of the presence of $P$. hydrophilum in Uruguay (Rosengurtt et al., 1970) must be based on misidentification of P. modestum specimens.

An agronomic evaluation of lowlands of the "Cerrado" ecosystem in Central Brazil has uncovered the potential of $P$. hydrophilum as a source of forage during the dry period, when, in most grazing areas, only a limited amount of green matter is available for cattle (Zoby et al., 1987).

Paspalum palustre has a very restricted area of confirmed ocurrence in Brazil. So far, the species has only been found in Porto Murtinho (State of Mato Grosso do Sul), the southernmost Brazilian locality along the Paraguay river. It also occurs in Northern Argentina and Southern Paraguay (Quarín and Burson, 1991).

According to the literature, $P$. modestum and $P$. palustre are diploid $(2 \mathrm{n}=2 \mathrm{x}=20)$, self-incompatible sexual species (Quarín and Hanna, 1980; Honfi et al., 1990; Quarín and Burson, 1991). Based on Argentinian populations, Paspalum hydrophilum was initially described as a tetraploid $(2 \mathrm{n}=4 \mathrm{x}=40)$ (Quarín, 1977), and a facultative apomictic species (Norrmann, 1981). However, diploid plants with regular meiosis (Pozzobon and Valls, 1987), as well as a triploid plant (Honfi et al., 1990), were detected in Brazilian materials.

The present paper compiles results of chromosome counts of an expanded array of accessions of the three species, collected in different regions of Brazil, to fundament subsequent steps of selection for direct use, as well as for use in more comprehensive Paspalum breeding programs.

\section{Material and Methods}

Table I shows the origin, collector's numbers, and the Brazilian accession codes of the materials studied. Voucher herbarium specimens were prepared of each accession that presented flowering in nature or in the screenhouse, and deposited at the Embrapa Recursos Genéticos e Biotecnologia (CENARGEN) herbarium (CEN), Brasília, DF.

All accessions studied have been maintained as live plants in a screenhouse at CENARGEN, and many are available in field plots at several Embrapa units, for agronomic evaluation.

For mitotic studies, root tips were pretreated with a saturated solution of 1-bromonaphthalene for $2 \mathrm{~h}$ at room temperature, and immediately hydrolyzed with $1 \mathrm{~N} \mathrm{HCl}$ for $11 \mathrm{~min}$ at $60^{\circ} \mathrm{C}$, without previous fixative treatment. Then they were stained following the Feulgen method (Sharma and Sharma, 1980) and squashed in 2\% acetic-orcein solution. Observations were made by light microscopy, and at least 10 metaphase cells were analyzed per accession.

\section{Results and Discussion}

The data obtained from the available Brazilian germplasm (Table 1 and Figure 1), indicate that the diploid level $(2 \mathrm{n}=20)$ is the most frequent in $P$. modestum and $P$. hydrophilum.

In $P$. modestum, four of the additional accessions were diploid, and three were tetraploid. Diploid level and regular pairing, mostly forming 10 bivalents in diacinesis and metaphase I, were first mentioned by Quarín and Hanna (1980). A diploid level was also confirmed in two South-Brazilian accessions (V 12325, V 12473), previously analyzed by Honfi et al. (1990). Argentinian plants analyzed by the same authors consistently showed a diploid level. The tetraploid level, reported here for Brazilian $P$. modestum plants, was previously unknown. Although both ploidy levels were present, the accessions were morphologically not very variable.

Five out of six new $P$. hydrophilum accessions were diploid. This level had been previously observed in a "Pantanal" accession (Pozzobon and Valls, 1987). Of the Brazil-

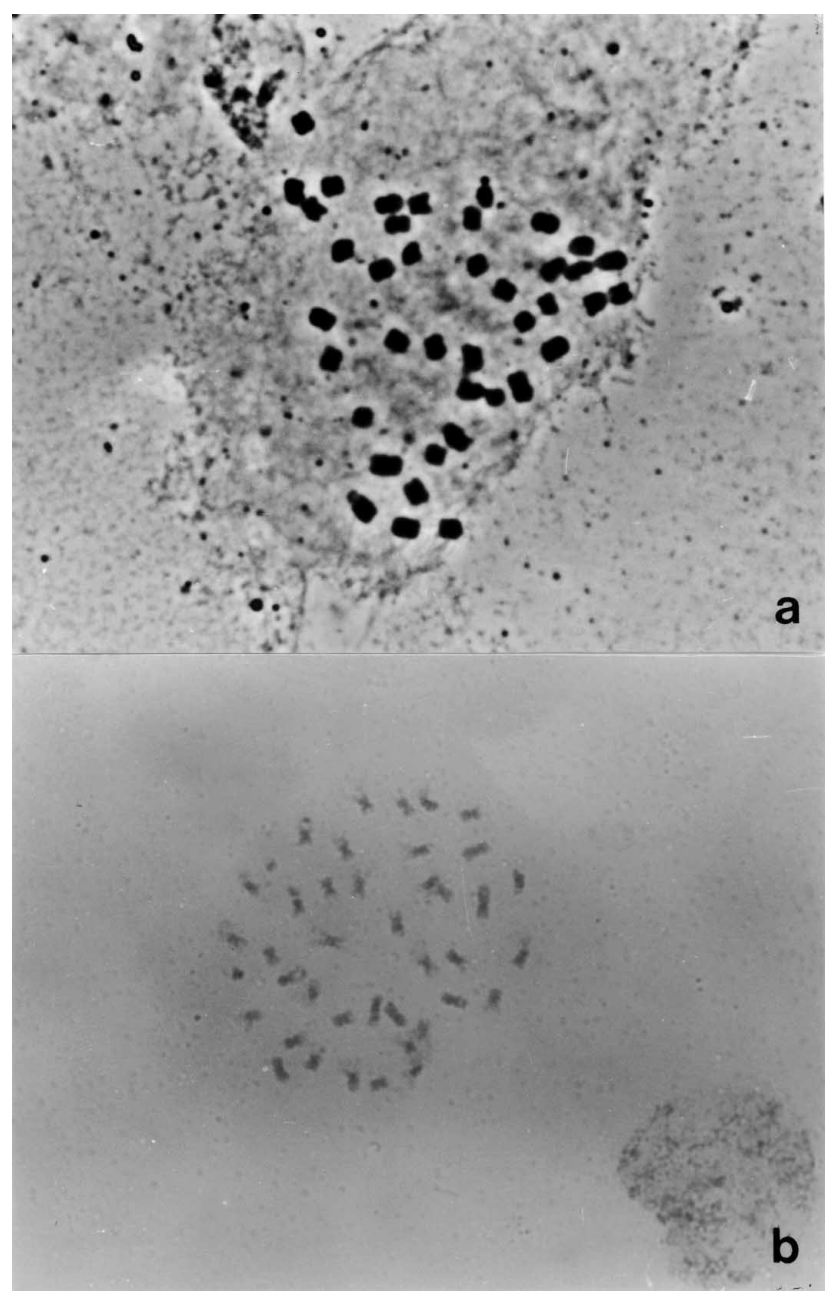

Figure 1 - Photomicrographs of mitosis: a) metaphase plate of $P$. modestum (tetraploid, $2 \mathrm{n}=40$; accession V 10045); b) metaphase plate of $P$. palustre (tetraploid, $2 \mathrm{n}=40$; accession V 13565). 
Table 1 - Chromosome numbers of Paspalum modestum and P. hydrophilum, origin of materials studied, and references.

\begin{tabular}{|c|c|c|c|c|}
\hline $\begin{array}{l}\text { Species/Accession } \\
\text { codes (BRA-) }\end{array}$ & $\begin{array}{l}\text { Collector identification } \\
\text { numbers }\end{array}$ & $2 n$ & Localities & Previous counts \\
\hline \multicolumn{5}{|l|}{ P. hydrophilum } \\
\hline 002399 & AVi 2511 & & BRA, MT, Barão de Melgaço & $2 n=20 ;$ Pozzobon and Valls, 1987 \\
\hline 014915 & Po 2114 & 20 & BRA, MS, Corumbá & \\
\hline 010421 & VPoJSv 10370 & 20 & BRA, MS, Corumbá & \\
\hline 010499 & VPoJSv 10425 & 20 & BRA, MS, Aquidauana & \\
\hline 010618 & VPoJSv 10508 & 20 & BRA, MT, N. Sra. do Livramento & \\
\hline 017990 & VGaRoSv 12560 & 20 & BRA, MT, S. José do Xingú & \\
\hline 007455 & AVi 2747 & & BRA, MS, Miranda & $2 \mathrm{n}=30 ;$ Honfi et al., 1990 \\
\hline$\overline{ }$ & Q 3079 & & ARG, CH, Makallé & 2n = 40; Quarín, 1977 \\
\hline 010286 & VJSv 10317 & 40 & BRA, MS, Corumbá & \\
\hline \multicolumn{5}{|l|}{ P. modestum } \\
\hline 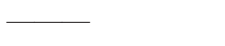 & Q 3591 & & ARG, CTES, Riachuelo & 2n = 20; Quarín and Hanna, 1980 \\
\hline- & Q 4030 & & ARG, CTES, Esquina & $2 \mathrm{n}=20 ;$ Honfi et al., 1990 \\
\hline - & Q 4031 & & ARG, CTES, 9 de Julio & $2 \mathrm{n}=20 ;$ Honfi et al., 1990 \\
\hline - & Q 4032 & & ARG, CTES, Goya & $2 \mathrm{n}=20 ;$ Honfi et al., 1990 \\
\hline- & Q 4033 & & ARG, CTES, Corrientes & $2 \mathrm{n}=20 ;$ Honfi et al., 1990 \\
\hline 006203 & VGzLeBo 9627 & 20 & BRA, RS, Santana do Livramento & \\
\hline 006491 & VMrFrLw 9774 & 20 & BRA, RS, Uruguaiana & \\
\hline 009831 & VBoSnSv 10027 & 20 & BRA, RS, Palmares do Sul & \\
\hline 017141 & VMrZnW 12325 & 20 & BRA, RS, Dom Pedrito & $2 \mathrm{n}=20 ;$ Honfi et al., 1990 \\
\hline 018210 & VMrLe 12473 & 20 & BRA, RS, Bagé & $2 \mathrm{n}=20 ;$ Honfi et al., 1990 \\
\hline 018610 & VGoMiOv 12819 & 20 & BRA, RS, Uruguaiana & \\
\hline 006386 & VMrFrLw 9733 & 40 & BRA, RS, São Gabriel & \\
\hline 009776 & VBoIrSv 9880 & 40 & BRA, RS, Rio Grande & \\
\hline 009857 & VBoSnSv 10045 & 40 & BRA, RS, Mostardas & \\
\hline \multicolumn{5}{|l|}{ P. palustre } \\
\hline$\longrightarrow$ & Q 3648 & & ARG, $\mathrm{CH}$, Antequeras & 2n = 20; Quarín \& Burson, 1991 \\
\hline 020214 & VRcSgSv 13565 & 40 & BRA, MS, Porto Murtinho & \\
\hline
\end{tabular}

Collectors: A = A. Allem; Bo = S. Boechat; Fr = J. Freitas; Ga = M. Galgaro; Go = K. Gomes; Gz = S. Gonzaga; Ir = B. Irgang; J = L.Jank; $\mathrm{Le}=$ E.Lemos; Lw = H. Longhi-Wagner; Mi = S. Miotto; Mr = C. Moraes; Ov = J. Oliveira; Po = A. Pott; Q = C. Quarín; Rc = R. C. Oliveira; $\mathrm{Ro}=\mathrm{D}$. Rocha; Sg = A. K. Singh; Sn = A. Santos; Sv = G. Silva; V = J. Valls; Vi = J. Vieira; W = W. Werneck; Zn = A. Zanin.

ian accessions now analyzed, only one was tetraploid. Furthermore, Honfi et al. (1990) determined 2n $=30$ for an accession collected in the state of Mato Grosso do Sul (AVi 2747). Morphological variation is easily noticeable among the Brazilian P. hydrophilum accessions. Plant height and hairiness, width of leaf blades, number of inflorescence branches, and spikelet size display a visible reticulate variation, both between representatives of distinct ploidy levels and between accessions with the same somatic number.

The results obtained in this study showed that the available $P$. hydrophilum germplasm is interesting for cytogenetic studies, as it comprises diploids with regular meiosis, indicative of sexuality, as well as triploids and tetraploids, which are possibly apomictic. Similar comments could be made regarding $P$. modestum, in which two levels were detected, but studies of meiotic behavior and embryo sac development at the tetraploid level are still required for this species. The same applies to $P$. palustre, previously known as a diploid only cytotype from the Argentinian Chaco, and now also found with tetraploid level.

The results of the present study support the observation that the coexistence of diploid and tetraploid cytotypes is the rule for most Paspalum species (Quarín, 1992).

Due to their apparent closeness to the agronomically important group Plicatula, where tetraploidy and apomixis are largely predominant, the species here studied could be used in phylogenetic studies. Such studies were started by Quarín (1983), involving the similarly important group Notata. In an attempt to investigate possible relationships 
between genomes, that author crossed tetraploid $P$. notatum Fluegge and diploid $P$. modestum. Chromosome associations found in the triploid hybrid, mostly 10 univalents and 10 bivalents, suggested that $P$. notatum had contributed with two homologous genomes (NN), while $P$. modestum had contributed with a single, distinctive genome (P).

Diploid cytotypes of the three species above may prove useful as bridge species for gene transfer in forage breeding programs involving Paspalum hybridization. In parallel, apomictic triploids and tetraploids might be selected directly as prospective new cultivars for the establishment of permanent high-quality pastures in areas subject to flood.

\section{References}

Allem AC and Valls JFM (1987) Recursos Forrageiros Nativos do Pantanal Mato-grossense. Brasília, EMBRAPA, 339 p.

Araújo AA (1934) A grama de Santa Carmen (Paspalum modestum Mez). Egatea 19:317-8.

Araújo AA (1971) Principais Gramíneas do Rio Grande do Sul. Porto Alegre, Sulina, $225 \mathrm{p}$.

Barreto IL (1954) Las espécies afines a Paspalum virgatum en la América del Sur. Revista Argentina de Agronomía 21:125142.

Barreto IL (1974) O genêro Paspalum (Gramineae) no Rio Grande do Sul. Tese de Livre Docência, Universidade Federal do Rio Grande do Sul Faculdade de Agronomia, Porto Alegre.

Burkart A (1969) Flora Ilustrada de Entre Ríos (Argentina). Parte II: Gramíneas. Buenos Aires, INTA [Paspalum L. p 369411].

Chase A (1929) The North American species of Paspalum. Contributions from the United States National Herbarium 28:1310.I-XVII.
Henrard JTh (1922) Paspalum hydrophilum spec. nov., aus Paraguay. Mededeelingen van's Rijks Herbarium Leiden n. 45:1-2.

Honfi AI, Quarín CL and Valls JFM (1990) Estudios cariológicos en gramíneas sudamericanas. Darwiniana 30:87-94.

Norrmann GA (1981) Citología y método de reproducción en dos especies de Paspalum (Gramineae). Bonplandia 5:149-158.

Pozzobon MT and Valls JFM (1987) Caracterização citogenética em acessos de germoplasma de espécies brasileiras de Paspalum (Gramineae). Encontro Internacional sobre Melhoramento Genético de Paspalum, Nova Odessa, 1987. Anais... Nova Odessa, São Paulo, pp 73-7.

Quarín CL (1977) Recuentos cromosómicos en gramíneas de Argentina Subtropical. Hickenia 1:73-76.

Quarín CL (1983) Híbridos interespecíficos de Paspalum notatum $x$ P.modestum. Bonplandia 5:235-242.

Quarín CL (1992) The nature of apomixis and its origin in panicoid grasses. Apomixis Newsletter 5:8-15.

Quarín CL and Burson BL (1991) Cytology of sexual and apomictic Paspalum species. Cytologia 56:223-228.

Quarín CL and Hanna WW (1980) Chromosome behavior, embryo sac development and fertility of Paspalum modestum, $P$. boscianum and $P$. conspersum. Journal of Heredity 71:419-422.

Rosengurtt B, Arrilaga de Maffei BR and Izaguirre de Artucio P (1970) Gramineas Uruguayas. Universidad de la República. Montevideo, $491 \mathrm{p}$.

Sharma AK and Sharma A (1980) Chromosome techniques: theory and practice, 3rd ed, Butterworth, Woburn, MA, p 95105.

Zoby JLF, Grof B, Andrade RP, Souza FB, Kornelius E, Valls JFM and França-Dantas MS (1987) Seleção de Paspalum spp. para produção de forragem em solos de várzea na região dos cerrados. 24 Reunião Anual da Sociedade Brasileira de Zootecnia, Brasília, DF, Anais... Brasília, p 228.

Editor: Marcio de Castro Silva-Filho 